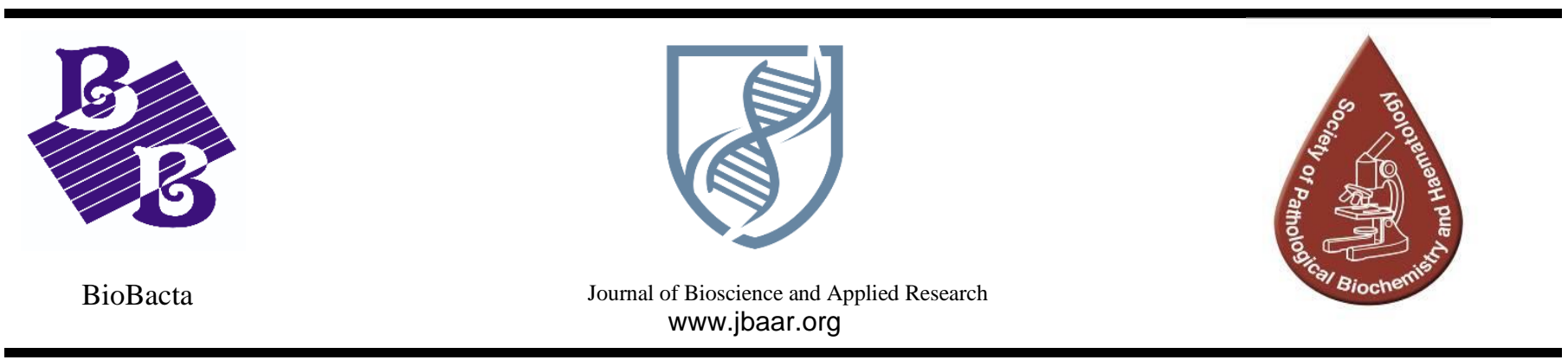

\title{
Preliminary Phytochemical Evaluation and chemical Composition of Gum Isolated from Fenugreek Seeds
}

\author{
Bushra B. G. Al-Shamari, Rawdhah M. A. Al-Ali, and Ali A. S. Al-Sahi \\ Department of Food Sciences, College of Agriculture, University of Basrah, Iraq \\ DOI: 10.21608/jbaar.2020.119301
}

\begin{abstract}
:
The present study aimed to extract the gum from fenugreek seed and studying the chemical composition, the preliminary phytochemical, and the flow properties. The extraction was conducted under different conditions (temperature, soaking period, and mixing ratios of seeds: water). The highest yield was of the fenugreek gum was $30.44 \%$ around $1: 25 \mathrm{w} / \mathrm{v}$ at $40 \mathrm{C}^{\circ}$ for $4 \mathrm{~h}$. Preliminary qualitative chemical test for gum shows the presence of carbohydrate, protein, amino acids, fixed oil, fats, and Ruthenium red while Arabic gum and Acacia showed that carbohydrates were only found, the fenugreek gum had $9.4 \%$ moisture, $2.3 \%$ ash, $2.49 \%$ protein and $0.9 \%$ fat. The total polysaccharide content of isolated gum was determined spectrophotometrically using the phenol-sulphuric acid method. The total polysaccharide content was $84.75 \%$. Arabic gum and Acacia had 5.44, $5.56 \%$ moisture, 3.74, $2.975 \%$ Ash, $0.0 \%$ protein, $0.0 \%$ fat and $90.80,91.25 \%$ carbohydrates. The gum showed good flow properties it has good viscosity of $72.40 \mathrm{CP}$ compared to the Arabic gum and Acacia 9.1, 9.61 CP higher concentration of $\mathrm{NaCl}$ and $\mathrm{CaCl}$ caused a larger decrease in viscosity, increasing or decreasing the $\mathrm{pH}$ and temperature led to the decrease of viscosity, and micrometric properties such bulk density, tapped density, Hausner's ratio, Carr's index, particle size and Angle of repose Bulk density was found to be $0.37 \mathrm{~g} / \mathrm{ml}$, tapped density was $0.58 \mathrm{~g} / \mathrm{ml}$, Carr's index was $36.20 \%$, Hausner's ratio 1.56 and Angle of repose was found to be 34.02.
\end{abstract}

Keywords: Fenugreek seeds gum, yield, Phytochemicals, Extraction, chemical analysis

Received: March 17, 2020. Accepted: September 20, 2020. Published: September 27, 2020

\section{Introduction}

Fenugreek is an erect annual plant, botanically known as Trigonella foenum graecum (Family: Leguminosae). The seed of fenugreek contains 3-6\% moisture, $25-30 \%$ protein, $20-25 \%$ insoluble fibers, and $3-4 \%$ Ash. The potential fenugreek gum could be significant in the food industry such as a spica vegetable and medicinal plant (Roberts et al, 2012). Fenugreek gum is extracted with water or dilute alkali from the endosperm or ground whole seed. From various reports the yield can be from 13.6 to $38 \%$, depending on cultivar and extraction procedure (Repin, 2016). The galactomannan is polysaccharides composed of linear (1-4) - D- mannan backbone with varying amounts of single D-galactose units attached to the main backbone by (1-6) glycosides bond (Kay, 2016). Fenugreek seed produces high viscosity gum at low concentration levels which do not dissolve in water and form a viscous tacky mass when exposed to fluids (Kumar et al., 2014). Fenugreek gum also has a 
strong surface activity in solution, making it a strong emulsifier and stabilizer for oil in water emulsions. In the food industry, fenugreek gum is less utilized for its thickening, stabilizing, and emulsifying properties, compared to other gum, however, it is an ideal candidate to be used in baking, bread making, gravies and soups, chocolate, and ice cream (Seetharaman et al. , 2016; kay, 2016). Has been extensively used in the pharmaceutical industry as a binder, gelling agent, emulsifier, and suspending (Mundhe et al, 2012).

The aim of the study is to study the effect the extraction was conducted under different conditions (temperature, soaking period, and mixing ratios of seeds: water). on the yield gum, a chemical composition such moisture, protein, fat, ash and carbohydrate, micrometric properties such bulk density, tapped density, Hausner's ratio, carr's index, particle size and angle of repose

\section{Material and methods}

Fenugreek seeds was obtained from the local market in Basrah city. The seeds were powdered using a coffee grinder. Arabic gum was obtained from BDH (England). All the other solvent reagents and chemicals used were analytical grades.

\section{Extraction of gum}

The fenugreek seeds gum was extracted by the method described by Nazni and vignesnwar (2014). The fenugreek powder was soaked in distilled water in a ratio $(1: 10 \mathrm{w} / \mathrm{v})$ and kept under shaking for $4 \mathrm{~h}$ at $40 \mathrm{C}^{\mathrm{o}}$, the viscous solution obtained was filtered through a muslin cloth. Ethanol $(99 \%)$ was added in the ratio $1: 1$ to precipitate out gum present the gum was dried in the oven at temperature 40-45 $\mathrm{C}^{\circ}$. The dried gum was stored in an airtight container.

\section{Effect of Extraction condition on the Recovery.}

The effect of extraction was analyzed. The extraction conducted under different conditions and the gum yield was calculated. The best dilution with maximum gum yield was selected for further analysis using different soaking periods such 4,6 , and $8 \mathrm{~h}$, and gum yield in percentage was analyzed.

\section{Extraction conditions}

\begin{tabular}{|c|c|}
\hline Powder : water & Temperature \\
\hline $1: 10$ & $40 \mathrm{C}^{\mathrm{o}}$ \\
\hline $1: 15$ & $60 \mathrm{C}^{\mathrm{o}}$ \\
\hline $1: 20$ & $80 \mathrm{C}^{\mathrm{o}}$ \\
\hline $1: 25$ & \\
\hline
\end{tabular}

\section{Chemical analysis}

Determination of moisture content. The extracted gum was dried in an oven for $3 \mathrm{~h}$ at $105 \mathrm{C}^{\mathrm{o}}$ according to the following AOAC (1984).

Determination of protein content. Nitrogen was determined by a semi-micro khjeldan (Pearson, 1970). Protein content was determined by multiplying nitrogen percent by the factor 6.25 .

Determination of Ash content. The ash content was determined according to AOAC (1984) method ovendried gum was weighted and was ignited in a furnace at $550 \mathrm{C}^{\circ}$ until light gray Ash produced.

Determination of Fat content. Fat was determined using soxhlet according to AOAC (1984).

Determination of polysaccharide content. The total polysaccharide contents of fenugreek gum were determined by using the phenol - sulphuric acid method according to the following Pawar \& Jadhav (2015).

\section{Preparation of standard curve}

Preparation of blank solution: To a test tube containing $1 \mathrm{ml}$ of distilled water, $1 \mathrm{ml}$ of $5 \%$ phenol was added followed by the addition of $5 \mathrm{ml}$ of concentrated sulphuric acid.

\section{Preparation of standard solution}

A stock solution of $100 \mathrm{mg} / \mathrm{ml}$ of glucose was prepared by dissolving $0.01 \mathrm{~g}$ of the standard glucose in distilled water $(100 \mathrm{ml})$ Aliquots were withdrawn from the stock solution to get sugar concentration $60 \mathrm{mg} / \mathrm{ml}, 70$ $\mathrm{mg} / \mathrm{ml}, 80 \mathrm{mg} / \mathrm{ml}, 90 \mathrm{mg} / \mathrm{ml}$ and $100 \mathrm{mg} / \mathrm{ml}$ to every 1 $\mathrm{ml}$ of sugar solution, $1 \mathrm{ml}$ of $5 \%$ phenol solution was added followed by addition of $5 \mathrm{ml}$ of concentrated sulphuric acid. The absorbances were determined after 10 minutes at 488nm against blank.

\section{Preparation of gum solution}

$0.1 \mathrm{~g}$ of gum powder was dissolved in $100 \mathrm{ml}$ of distilled water. From this $1 \mathrm{ml}$ was used for sugar analysis, to determinate the polysaccharide content in 
fenugreek seeds gum and Arabic gum, and Acacia. 1m of $5 \%$ phenol added to the $1 \mathrm{ml}$ of gum solution followed by the addition of $5 \mathrm{ml}$ concentrated sulphuric acid. The absorbances were determinate after 10 minutes at $488 \mathrm{~nm}$ against a blank. The experiment was carried out in triplicate (i.e Test-1, Test-2, and Test-3)

Determination of purity of fenugreek gum. Preliminary tests of gum were performed to confirm the purity of gum obtained according to Poonkotha and Selvis (2015). Assie tal, (2017)

\section{Test for carbohydrate}

\section{a- Molisch test}

This test is used to confirm the presence of carbohydrate in the mucilage $1 \mathrm{ml}$ of $1 \%$ gum solution has been placed in a clean test tube, then, two drops of the freshly prepared molisch reagent were introduced. Finally, concentrated sulfuric acid has been added gradually to the side of the tube to form a layer above the aqueous solution. A violet ring was observed at the junction of two layers

b- Barfoed s test: To the $1 \%$ gum solution $1 \mathrm{ml}$ of barfoed reagent was added and boiled in a water bath for 5. Brick-red precipitate formation shows the presence of carbohydrate.

c- benedict $\mathrm{s}$ test : To the $1 \%$ gum solution added $1 \mathrm{ml}$ Benedict s reagent and boiled in a water bath for 5 . green reddish-brown precipitate indicates the presence.

d- Bial test: to the $1 \%$ gum solution added 3 drops of $\mathrm{HCl}$ and $1.5 \mathrm{ml}$ bial regent and boiled in a water bath for 3. The appearance of green color indicates the presence of fifty sugars.

e- lodine test: To the $1 \%$ gum solution added $1 \mathrm{ml} 0.2$ $\mathrm{N}$ iodine solution in a test tube and the mixture has been observed no color was developed in solution confirm the presence of starch.

\section{Red ruthenium test}

$0.1 \mathrm{~g}$ of dried gum was placed on a slide with 3 drops of red ruthenium solution was added and the whole has been observed under a microscope appearance of pink color indicates the presence plant gums

Test for Amino acid/protein
Ninhydrin test: Heated the $1 \mathrm{ml}$ of $1 \%$ gum solution and $1 \mathrm{ml}$ of Ninhydrin solution in a boiling water bath for 10 minutes. The appearance of purple color shows the presence of amino acids

Test for phenolic compounds: To $1 \mathrm{ml}$ of $1 \%$ gum solution added $1 \mathrm{ml}$ of $1 \%$ neutral ferric chloride solution formation of blackish-blue color indicates the presence of phenolic compounds.

\section{Test for alkaloids}

Wagner s test: To $1 \mathrm{ml}$ of $1 \%$ gum solution was added 2 drops of Wagner reagent. formation of reddish-brown precipitate indicates the presence of alkaloids

\section{Test Flavonoids}

Alkaline reagent test $/ \mathrm{NaOH}$ test: To $1 \%$ gum solution added 2 drops of sodium hydroxide solution. Appearance yellow color which disappeared after adding $0.5 \mathrm{~N} \mathrm{HCl}$ indicates the presence of flavonoids.

\section{Test for glycosides}

Borntrager s test: Added 3 drops of $1 \mathrm{~N}$ sulphuric acid to $1 \mathrm{ml}$ gum solution. Boiled and added $1 \mathrm{ml}$ of chloroform, the chloroform layer is treated with $1 \mathrm{ml}$ of ammonia, the formation of red color of the ammonical layer shows the presence of glycosides.

\section{Test for fix oils and fats}

Saponification test: To $1 \mathrm{ml}$ of gum solution added 2 drops of $0.5 \mathrm{~N}$ alcoholic potassium hydroxide along with a one drop of phenolphthalein. Heat the mixture on a water bath for 1-2 hours, the formation of soap indicates the presence of fixed oils and fats

\section{Test for sterols}

Salkowski test: $1 \mathrm{ml}$ of concentrated sulphuric acid was added to $1 \mathrm{ml}$ of $1 \%$ gum solution and mixed well. $1 \mathrm{ml}$ of chloroform was added, the appearance of red color in the lower layer indicates the presence of sterols

\section{Evaluation of micromeretic studies of gums}

\section{Viscosity measurement}

The flow time for a $1 \%$ aqueous solution of fenugreek gum was determined using capillary viscometer size $\mathrm{C}$ at $25 \mathrm{C}^{\circ}$ Yusf ( 2011 ). The relative viscosity was calculated using the equation

Relative viscosity $\left(25 \mathrm{C}^{\mathrm{o}}\right)=\left(\mathrm{T}-\mathrm{T}^{\mathrm{o}}\right) \mathrm{T}^{\mathrm{o}}$ 
Where: $\mathrm{T}$ is the flow time of gum solution (sec.)

$\mathrm{T}^{\mathrm{o}}$ is the flow time of distilled water (sec.)

\section{Bulk and tapped densities}

A $2 \mathrm{~g}$ quantity of each of the powder was placed in a $10 \mathrm{ml}$ measuring cylinder and the volume, V0 occupied by each of the samples without tapping was noted. After 100 taps on the table, the occupied volume V100 was read according to Emeje et al. (2011).

\section{Hausner index}

This was calculated as the ratio of tapped density to bulk density of the sample according to Farooq et al. (2014).

\section{Compressibility index}

This was calculated using the following equation according to Farooq et al. (2015).

Compressibility $=$ Tapped density - Bulk density )/tapped density $\times 100$.

\section{Angle of repose}

The angle of repose was calculated according to Farooq et al. (2015), finely powdered 5g was passed through a funnel fixed on a stand at a specific height upon graph paper according to Farooq et al. (2015), and calculations were done as per equation

Tan $\theta=\frac{\text { Hight }}{\text { radius }}$

$\theta=\tan ^{-1} \frac{h}{r}$

$\theta=$ angle of repose

$\mathrm{h}=$ height of pile

$\mathrm{r}=$ radius of pile

\section{Particle size determination}

Dried Powdered gum was determined using an optical microscope according to Gupta et al. (2015), and calculated using the equation.

Size of the particle $=$ No. of Particles in eyepiece $\times$ Calibration factor
Calibration factor $=\frac{\text { Stage reading }}{\text { ocular reading }} \times 0.01$

Effect of temperature, $\mathrm{pH}$, and electrolytes on viscosity

Temperature

To determine the effect of temperature on viscosity of $1 \% \mathrm{w} / \mathrm{v}$ of fenugreek gum at $25-80 \mathrm{C}^{\mathrm{o}}$ according to Norbrillinda et al. (2014)

\section{PH}

To measure the viscosity at different $\mathrm{pH}$ (3-10). $\mathrm{PH}$ of $1 \%$ solution of fenugreek solution was measured using $\mathrm{pH}$ meter at $25 \mathrm{C}^{\mathrm{o}}$ with $\mathrm{pH} 3$ and 10 buffers for calibration, according to Norbrillinda et al. (2014).

\section{Salt}

The effect of chloride calcium and chloride sodium (0.2-1) molar on the viscosity of $0.5 \%$ solution gum according to Elijah et al. (2010).

\section{Statistical analysis}

All the chemical analysis were made triplicate. These data were analyzed using SPSS 2012, analysis of variance (Anova). Comparative analysis between parameters was carried out by L.S.D. With probability $(\mathrm{P}<0.05)$.

\section{Results and Discussion}

The results are illustrated in Figure 1 depicted the effect of ratios of powder: water on the yield of Fenugreek gum. The highest yield was obtained from $1: 25 \mathrm{w} / \mathrm{v} 20.44 \%$ whereas the minimum yield was observed for $1: 10 \mathrm{v} / \mathrm{w}$. The result showed significant differences in yield content in the fenugreek gum. These values are lower than those previously reported by Kumar et al., (2009). That the yield of fenugreek gum was $31 \%$ for $1: 10$ effect temperature. 


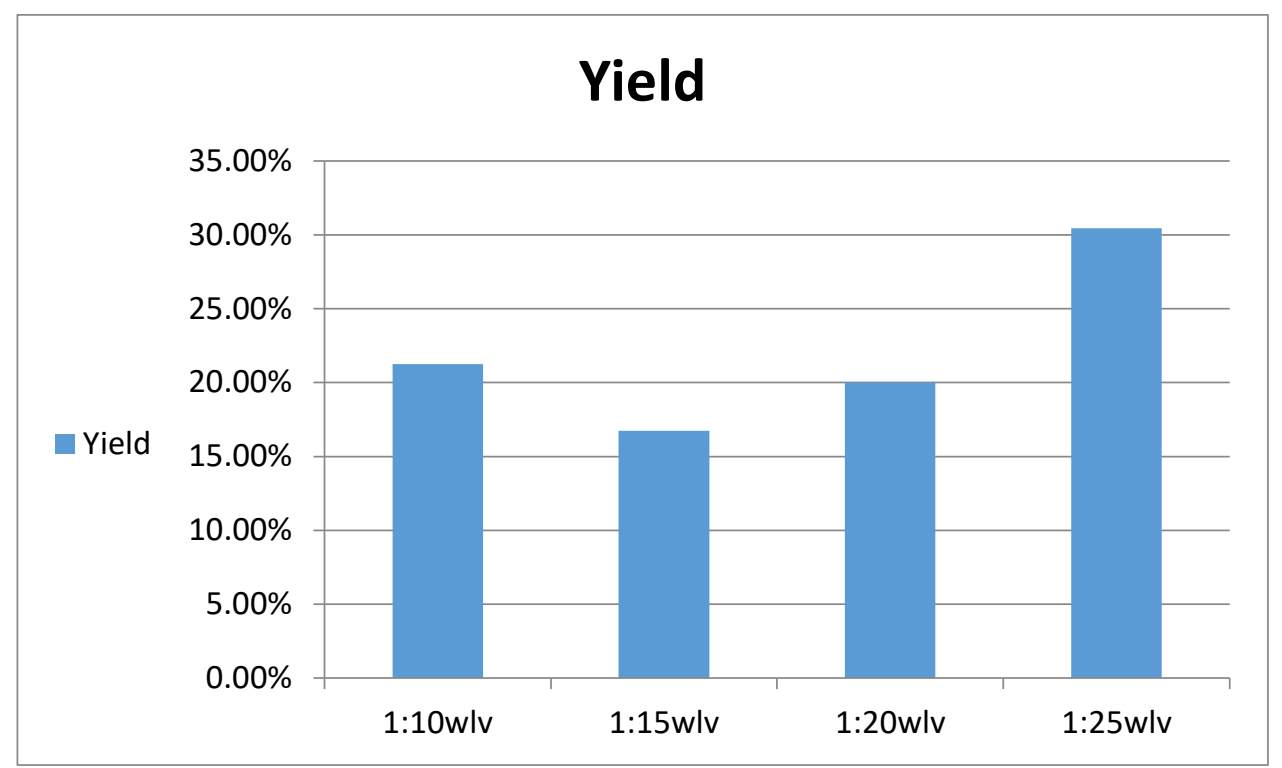

Fig1. Effect ratio of powder fenugreek seed: water on the yield.

The results are presented in Figure 2 indict the effect of different temperature levels 40,60, and $80 \mathrm{C}^{\circ}$ on the yield content of fenugreek gum. Fenugreek gum shows a higher yield at $40 \mathrm{C}^{\circ}(30.44 \%)$ while the lower yield at $80 \mathrm{C}^{\circ}(21.84) \%$ which clearly shows that temperature has a significant effect on the yield content, increase of temperature has broked the chain of gum

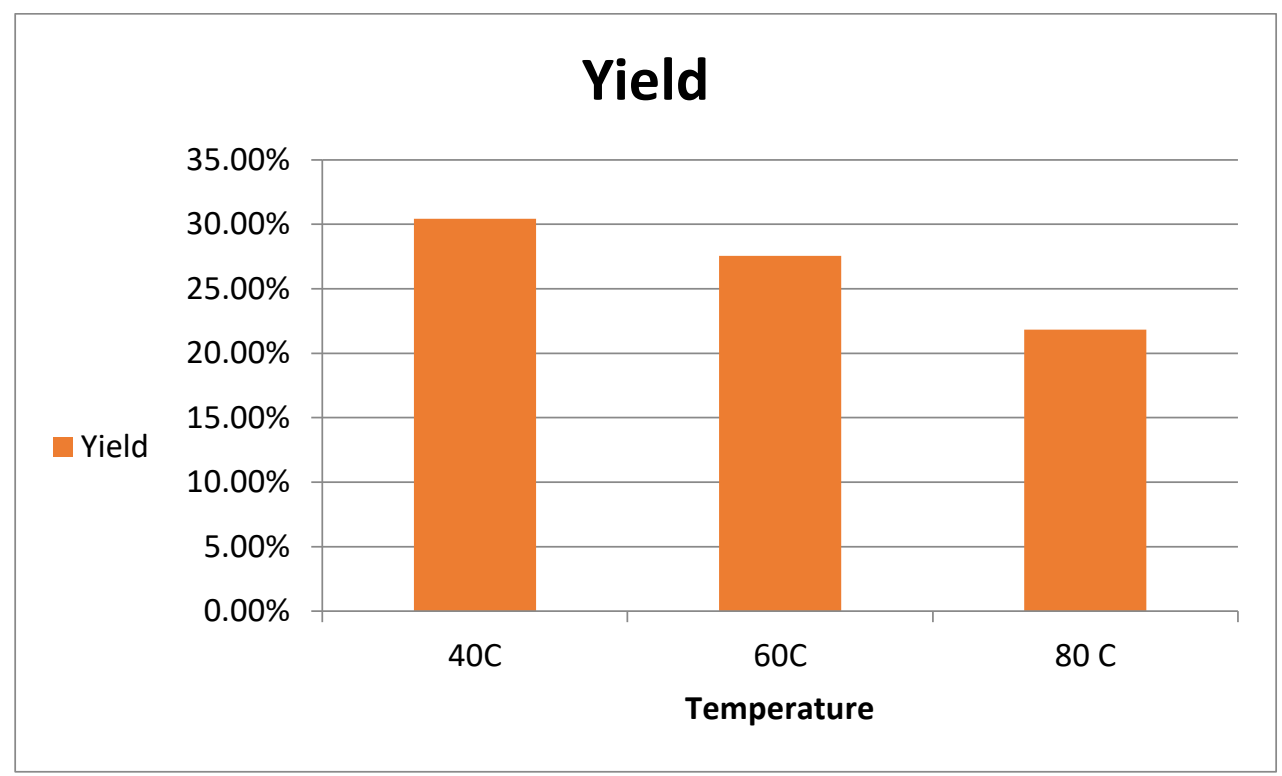

Fig2. Effect of different temperatures on the yield.

The results are presented in Figure 2 indict the effect of different temperature levels 40, 60, and $80 \mathrm{C}^{\mathrm{o}}$ on the yield content of fenugreek gum. Fenugreek gum shows a higher yield at $40 \mathrm{C}^{\mathrm{o}}(30.44 \%)$ while the lower yield at $80 \mathrm{C}^{\mathrm{o}}(21.84) \%$ which clearly shows that temperature has a significant effect on the yield content, increase of temperature has broked the chain of gum 


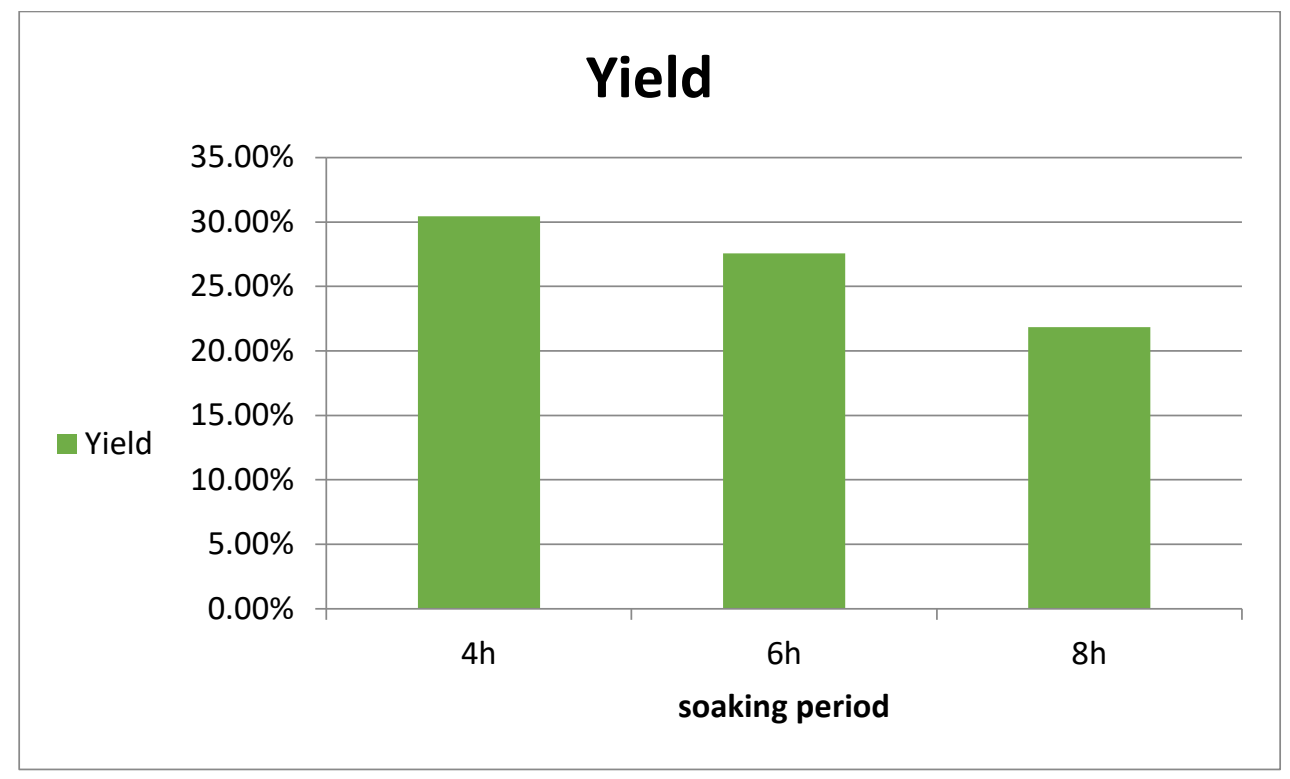

Fig3. Effect of soaking period on the yield.

The results are shown in Figure 3 The effect of soaking period on yield, it is clear that the fenugreek gum the highest yield at $4 \mathrm{~h} 30.44 \%$ and then decreased gradually at $8 \mathrm{~h} 29.42 \%$. This may high-temperature increase in macromolecular motion and solubilization of gum solution.

\section{Phytochemical test}

As shown in Table 1 the isolated gum gave positive test for carbohydrates, protein, fat, and ruthenium red and negative test for phenol compound ,alkaloids, flavonoids, starch, sterols glycosides and resins because the fenugreek gum was raw, while Arabic gum and Acacia were gave positive for carbohydrate and negative test for protein, fat, sterols, flavonoids, starch, glycosides and resins. The difference could be attributed to purity of Arabic gum and Acacia.

Table 1: Phytochemical tests of gums

\begin{tabular}{|c|c|c|c|}
\hline Test for phytoconstituents & Fenugreek gum & Arabic gum & Acacia gum \\
\hline Carbohydrate & & & \\
\hline$\bullet \quad$ Molisch's test & + & + & + \\
\hline$\bullet \quad$ Barfoeds test & + & + & + \\
\hline$\bullet \quad$ Benedicts test & + & + & + \\
\hline$\bullet \quad$ Iodine test & - & - & - \\
\hline Ruthenium red test & + & + & + \\
\hline Protein and Amino acid & + & - & - \\
\hline Alkaloid & - & - & - \\
\hline Glycoside & - & - & - \\
\hline Flavonoid & - & - & - \\
\hline Phenolic compounds test & - & - & - \\
\hline Resins test & - & - & - \\
\hline Sterols & - & - & - \\
\hline Fixed Oil & + & - & \\
\hline
\end{tabular}


The results are showed in Table 2, indicate the fenugreek had $9.4 \%$ moisture this indicates that the gum is hygroscopic in nature compared with the moisture content in the Arabic gum and Acacia (5.44, 5.56\%). The protein and fat content of fenugreek gum were found to be $2.49,0.9 \%$ respectively, that is higher than the protein and fat in Arabic gum $(0,0 \%)$ and Acacia $(0,0 \%)$. The difference may be attributed to the fenugreek gum was raw.

Table 2: chemical composition of gums

\begin{tabular}{|l|c|c|c|}
\hline Parameter & Fenugreek seeds gum & Arabic gum & Acacia gum \\
\hline Moisture (\%) & $9.4 \mathrm{a}$ & $5.44 \mathrm{~b}$ & $5.56 \mathrm{~b}$ \\
\hline Crude fat (\%) & $0.9 \mathrm{a}$ & $0 \mathrm{~b}$ & $0 \mathrm{~b}$ \\
\hline Protein $(\%)$ & $2.49 \mathrm{a}$ & $0 \mathrm{~b}$ & $0 \mathrm{~b}$ \\
\hline Ash $(\%)$ & $2.34 \mathrm{a}$ & $3.47 \mathrm{~b}$ & $2.97 \mathrm{~b}$ \\
\hline Carbohydrate & $84.75 \mathrm{a}$ & $90.80 \mathrm{~b}$ & $91.25 \mathrm{~b}$ \\
\hline
\end{tabular}

Means within the same parameter having different letters are significantly different $(\mathrm{P}<0.05)$

Ash value of isolated gum was found $2.34 \%$ that was lower than the ash content in Arabic gum 3.74\% and Acacia $2.97 \%$, the low value of ash show that fenugreek gum has a good quality of mineral content with a low level of contamination (Adeyanju et al., 2015). The fenugreek seed gum contains about $84.75 \%$ of polysaccharides slightly lower than the results obtained for the polysaccharides of Arabic gum $90.80 \%$ and Acacia $91.25 \%$, the ash content in the fenugreek gum in percent study that is higher than $1.02 \%$ that was reported by Verma et al., (2014).

\section{Evaluation of micromeretic studies of gums}

The results are illustrated in Table 3 indicate The relative viscosity of a $1 \%$ solution of fenugreek seeds gum investigated at $25 \mathrm{C}^{\mathrm{o}}$ was found to be $72.40 \mathrm{cp}$ that is higher than the viscosity of Arabic gum $9.1 \mathrm{cp}$ and Acacia $9.61 \mathrm{cp}$. The high viscosity of fenugreek seeds gum is due to a low branch, while branched binogalactan structure is responsible for the low viscosity of a solution of Arabic gum and Acacia gum (GmbH and KGaA, 2015).

Table 3: Micromeritic study data of gums

\begin{tabular}{|c|c|c|c|}
\hline Para meter & Fenugreek seeds gum & Arabic gum & Acacia gum \\
\hline Viscosity (C.P) & $72.40 \mathrm{a}$ & $9.1 \mathrm{~b}$ & $9.61 \mathrm{~b}$ \\
\hline Bulk Density (1m/g) & $0.37 \mathrm{a}$ & $0.90 \mathrm{~b}$ & $0.5 \mathrm{c}$ \\
\hline Tapped Density (ml/g) & $0.58 \mathrm{a}$ & $1 \mathrm{~b}$ & $0.55 \mathrm{c}$ \\
\hline Hausner s Ratio (\%) & $1.56 \mathrm{a}$ & $1.11 \mathrm{~b}$ & $1.1 \mathrm{~b}$ \\
\hline Carr s index (\%) & $36.20 \mathrm{a}$ & $10 \mathrm{~b}$ & $9.09 \mathrm{~b}$ \\
\hline mean particle size (M) & $88 \mathrm{a}$ & $7.5 \mathrm{~b}$ & $35 \mathrm{c}$ \\
\hline Anqle of vepose (0) & $34.02 \mathrm{a}$ & $21.80 \mathrm{~b}$ & $19.79 \mathrm{c}$ \\
\hline
\end{tabular}

Means within the same parameter having different letters are significantly different $(\mathrm{P}<0.05)$ 
Kumar et al (2014) reported the viscosity of $1 \%$ solution of fenugreek gum at $37 \mathrm{C}^{\mathbf{o}}$ to be found $39 \mathrm{cp}$ that is lower than is reported in this study. Bulk and tapped densities of powder fenugreek seeds were found to be $0.37 \mathrm{~g} / \mathrm{ml}, 0.58 \mathrm{~g} / \mathrm{ml}$ were low compared with Arabic gum 0.90, a $1 \mathrm{~g} / \mathrm{ml}$ and Acacia 0.5, $0.55 \mathrm{~g} / \mathrm{ml}$, the higher swelling index of fenugreek gum might be due to this low bulk and tapped density values (Samy et $a l, 2015)$. The bulk and tapped densities values of powder fenugreek gum in dictate that powder is heavy in nature, while the bulk and tapped densities values of powder Arabic gum and Acacia are light in nature. Bulk and tapped densities of the gum gave an insight into its flow properties packaging and arrangement of particles (Emeje et al, 2011). Hauser's ratio and compressibility of powder fenugreek gum around 1.56 and $36.20 \%$ respectively that were higher than the Hauser's ratio and compressibility of Arabic gum 1.11, $10 \%$ and Acacia $1.1,9.09 \%$. The carr's index and Hauser's ratio values of fenugreek gum indicate that powder has poor flow character, while shows Arabic gum and Acacia excellent flow properties, Verma et al., (2014) reported that the bulk density tapped density, Hauser's ratio, and compressibility of powder fenugreek were $0.66 \mathrm{~g} / \mathrm{ml}$, $0.94 \mathrm{~g} / \mathrm{ml}, 1.39$ and $28.2 \%$ that is higher than is results in this study. The obtained results show the bulk and tapped densities in powder fenugreek gum that is lower than $0.47 \mathrm{~g} / \mathrm{ml}, 0.52 \mathrm{~g} / \mathrm{ml}$ that was reported by Kumar, (2014). The results are showed irregular particle size was found to be $88 \mu \mathrm{M}$ compared with the particle size of Arabic gum $7.5 \mu \mathrm{M}$ and Acacia $35 \mu \mathrm{M}$. The angle of repose of the isolated gum was found to be 34.02. It found to be very high and this shows that fenugreek gum has more concessive properties than the Arabic gum and Acacia as the value of repose angle has been shown to be high powder is non-cohesive.

The effect of temperature, $\mathrm{pH}$, and salt on the viscosity of gums.

Temperature effect

The results are illustrated in Figure 4 indicate The effect of an increase of temperature on viscosity of $1 \%$ of fenugreek seeds gum solution in the range $30-80 \mathrm{C}^{\circ}$ compared with Arabic gum and Acacia solution. Fenugreek seeds gum had high thermal stability than Arabic gum and Acacia. The viscosity of Arabic gum and Acacia had been affected by the change of temperature. The result is in agreement with the reported by Norbrillinda et al. (2014). The viscosity of pineapple gum and locust bean gum decreased as the temperature increased from 10 to $70 \mathrm{C}^{\circ}$. The decrease in viscosity of gums was due to the increase in macromolecular motion and solubilization of gum solution at a higher temperatures.

\section{pH effect}

The results are depicted in Figure 5 indicate the plant gums solution showed the highest viscosity at $\mathrm{pH} 7$ and then decreased gradually at $\mathrm{pH} 3$ and $\mathrm{pH}$ 10. The viscosity increased over the $\mathrm{pH}$ values from 3 to 7 and then decreased with increasing $\mathrm{pH}$ from 7 to 10 . The result is in agreement with the reported by Norbrillinda et al. (2014). The viscosity of pineapple gum and locust bean gum decreased as $\mathrm{pH} 3$ and $\mathrm{pH} 10$. The decrease in viscosity of gums was due to the galactomannan can be destroyed and lose its viscosity at high and low $\mathrm{pH}$. Thanatcha and Pranee (2011) reported that increasing the $\mathrm{pH}$ and temperature led to a decrease of viscosity.

\section{Salt effect}

The results are presented in Figure 6, 7 the effect of $\mathrm{NaCl}$ and $\mathrm{CaCl}_{2}$ at concentration $0.2-1 \mathrm{M}$ on the viscosity of three plant gum solutions. It was observed that the viscosity of gums solution is decreased with increasing concentration of salt, positive ions by reducing the repulsive force in negatively charged molecules lead to a reduction in viscosity ( Mozafari et al, 2016 ), $\mathrm{CaCl}_{2}$ had a higher effect on viscosity of gums. The proximity of gums to metal ions depends on the ionic radius to charge ratio. It means that small ions with higher charge are stronger to link to the chain there for $\mathrm{Ca}^{+2}=2.1$ and $\mathrm{Na}=1$ ratio. The interaction of gums is higher with $\mathrm{Ca}^{+2}$ than $\mathrm{Na}$ (Mozafari et al, 2016). The result is in agreement with the reported by Chang et al. (2017). The viscosities of gum such as guar gum, locust Bean, tamarind, and flax seed gum decreased as the salt increase. 


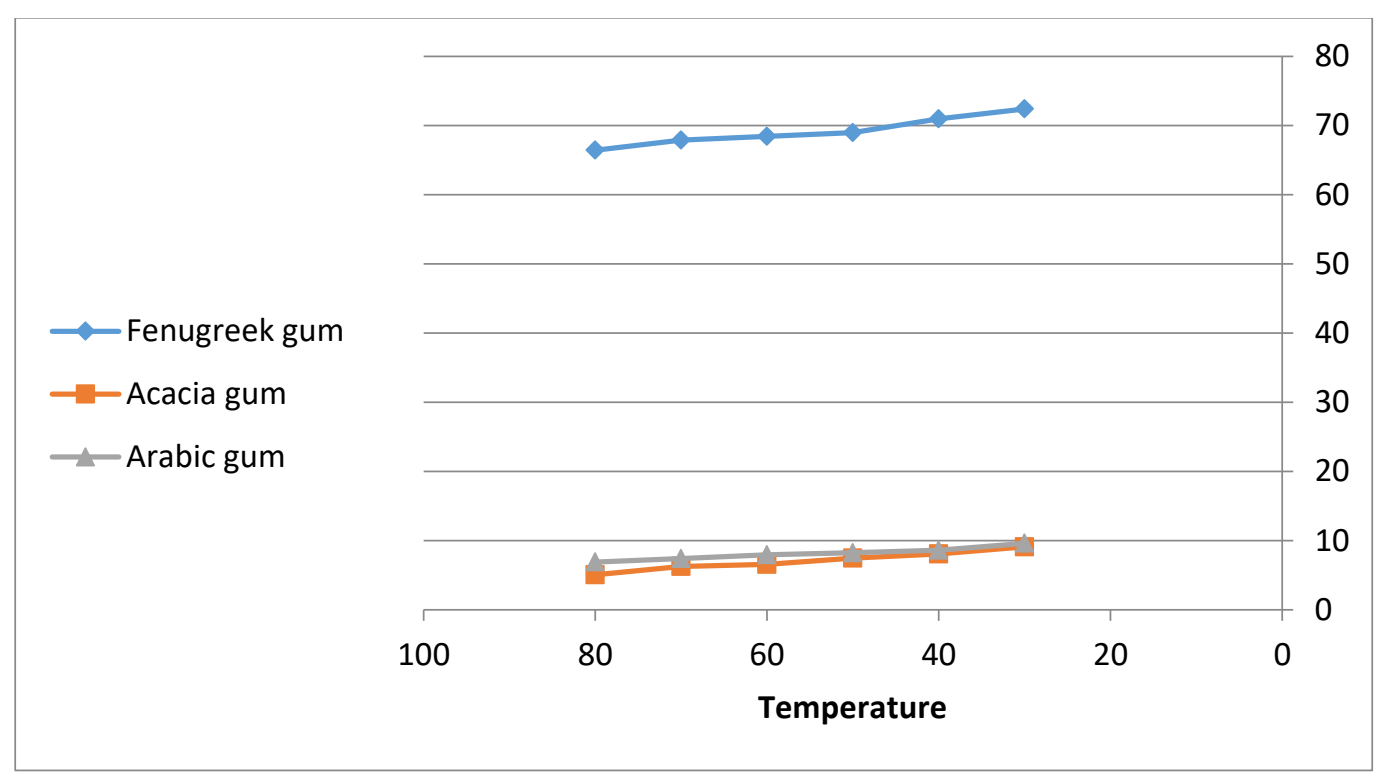

Fig 4. Effect of different temperatures on the viscosity of $1 \%$ gums solution.

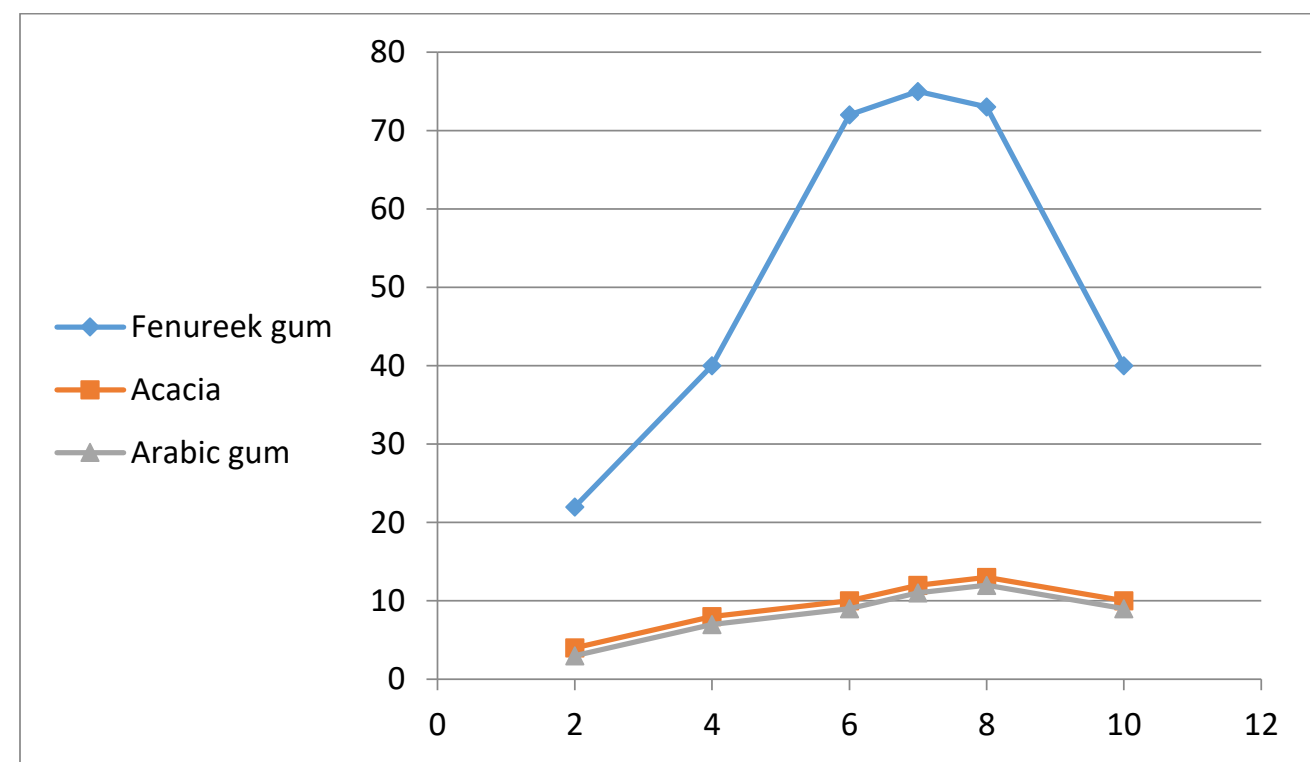

Fig 5. Effect of different levels of pH on the viscosity of $1 \%$ gums solution 


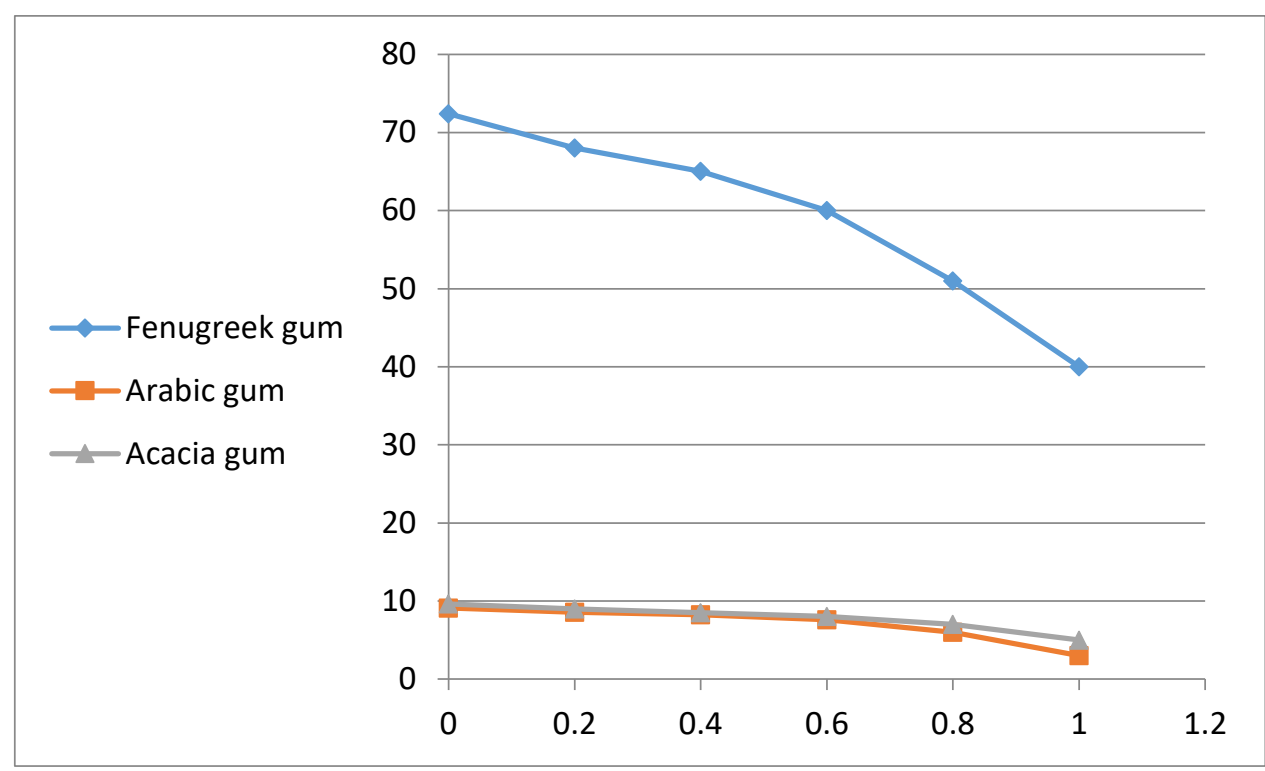

Fig 6. Effect of different concentration of $\mathrm{NaCl}$ on the viscosity of $1 \%$ gums solution.

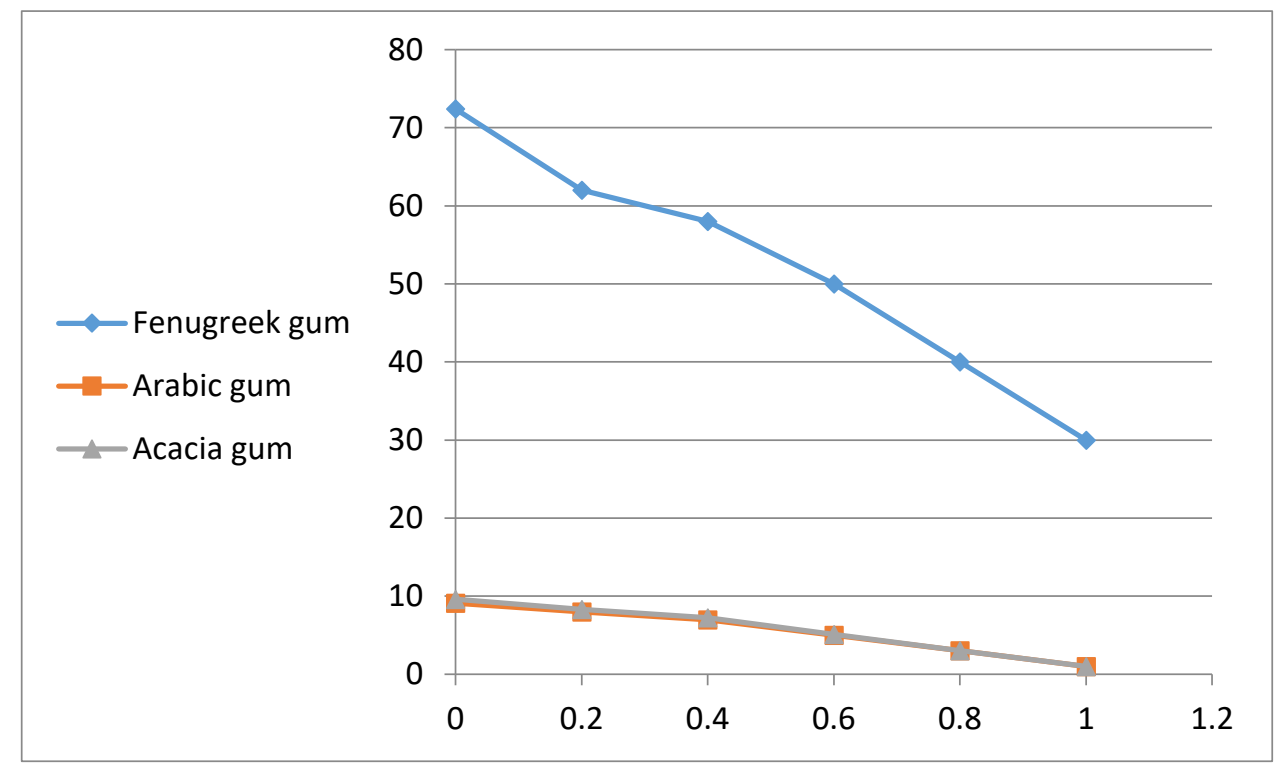

Fig7. Effect of different concentration of $\mathrm{CaCl}$ on the viscosity of $1 \%$ gums

\section{Conclusions}

The maximum yield of gum was $30.44 \%$ for the $1: 25$ dilution, soaking period for $4 \mathrm{~h}$ at $40 \mathrm{C}^{\mathrm{o}}$, the fenugreek seeds gum had the highest moisture, fat, protein, and viscosity than other gums, the temperature, $\mathrm{pH}$, and salts affected the viscosity of gums. The viscosity decrease with increasing the temperature, $\mathrm{pH}$, and concentration of salt. The study through some light on the understanding the gum potential applications in the food industry.

\section{References}

A.O.A.C. (1984). Association of Official Analytical Chemist's Official Methods of analysis, Washington, U. S. A.

Assi, O.Y. ; Sidibe, D. ; Konan, Y. N. ; Coulibaly, A. ; Mahan, R. M. and Biego, H. M. G. (2017). Viscosity Study of mucilage's extracted from Abelmoschuses culentus, Beilschmedia mannii, Corchorusolitorius and lrvingia gabonensis from Coted lvoire .Journal of Applied Life Sciences International , 11(1): 1-4. 
Adeyanju, Lajide L.,Ajayi o.,Amoo,1.,Plavec,J.(2015 ) . Physicochemical and structural characterization of Sweitenia mycrophylla gum. Scholars Academic Journal of Biosciences, 3(3):231-238.

Chang, Y. ; Li, Y. ; Miao, Q. ; Jiang, H. and Gao. X. (2017). Rheological Properties of six plant based seed gums. American Journal of Analytical Chemistry, 8:690-707.

Emeje, M., Isimi, C., Byrn, S. , Fortunak, J., Kunle, O. and Ofoefule, S. (2011). Extraction and physicochemical characterization of a new polysaccharide obtained from the fresh fruits of Abelmoschus esculentus. Iranian Journal of Pharmaceutical Research, 10(2): 237-246.

Faroog, U.; Malviya, R. ; Sharma, P. K. (2014). Extraction and characterization of Artocarpus integer gum as pharmaceutical Excipient. journal Polim Med,44 (2): 69-74.

Favooq, U. Malviya, R. and Sharma, k. (2015). Design and development of muti particulate system for tavgeted drug drug delivery using Natural polymer. Journal Pharmace utia analytica Acta, 6(5):1-8.

Gmbh,V. and Kgaa, C. (2015). Cellulose and Cellulose derivatives in the food in dustry. Fundamentals and Applications, First Edition.

Kumar, D. ; Singhal, A. ; Bansal, S. ; Gupta, S. K. (2014). Extraction, Isolation and Evaluation Trigonella foenum-graecum as mucoadhesive agent for nasal gel drug delivery, Journal of NPA, (1):40-45.

Kumar, R. ; Patil, S. ; Patil, M. B. ; Patil, S. R. ; Paschapur, M. S. (2009). Isolation and evaluation of disinter grant properties of Fenugreek seed Mucilage, International, Journal of Pharmtech Research, 4(1):982996.

Mundhe, M. R. ; Pagore, R. R. ; Biyani,K. R. (2012). Isolation and evaluation of Trigonella Foenum Graecum Mucilage as gelling agent in Diclofenac potassium gel International Journal of Ayurvedic and Herbal Medicine, 2(2):300-3006.

Nazni, P. and Vigneshwar, P. (2014). Study on extraction and organoleptic evaluation of okra and hxbiscus mucilage in corporate products. International Journal of Food and Nutritional Sciences, 3(1):99-103.

Noolraila,A.,Aziah,S.,A.,Asmeda,R.,Norizzah,A. ,R.(2015).Emulsifying properties of ex tracted okra (Abelmoschusesculentus L.) mucilage of different maturity index and its application in coconut milk emulsion.Lnternational food research journal 22(2) : $782-787$.

Novbrillinda, M. T. ; Anis, W. W. ; Hamimi, I. A. ; Madzlan, K. and Shazlin, K. (2014). Effect of temperature and $\mathrm{pH}$ on viscosity of pineapple gum. Journal Trop Agricultural and Food Sciences, 42(2):143-148.

Palanisamy, P. ; Jayavar, B. ; Kumuthavalli, M. V. Vsumar, Y. and Srinatn, V. R. (2012). Preliminary phytochemical, Evaluation of whole plant Extract of diptera canthus prostrates nees. In Ternational Research Journal of Pharmacy, 3(1):150-153.

Pawar,H,A., and Jaclhav,P.( 2015). Preliminary phytochemical evaluation and spectrophotometric estimation of total polysaccharide content of gum isolated from cordial dichotomafruits.Natural products chemistry\&Researm 3(2):1-3.

Pearson, D. (1976). The Chemical Analysis of Foods. 7th ed. Edinburgh; New York: Churchill Livingstone. PP: 575.

Poonkothai, M. \& Salvi, S. (2015). Phytochemical screening and antioxidant assay of agaricus bisporous while button mushroom), International Journal of Biological, 6(11):877-884.

Repin, N. (2016). Investigations of mechanisms in voived in postprandial Glycemia Attenuation with 
dietary fiber consumption. pHD. Thesis. The University of Guelph.

Roberts,K.,T.,Cui,S.,W.,Change,Y.,H.,Ng,P.,K., W.,Graham,T.(2012). The lnfluence of fenugreek gum and extrusion modifiedfenugreek gum on bread. Journal homepage

Seetharaman,S.,Balya1,H.,|Kuppusamy,G.(2016) .Preparationand evaluation of cefixime nanoparticles Prepared using fenugreek seed mucilage and chitosan as natural polymers.Lnternational journal of pharmaceutical and clinical 8(3): 179-188.

Verma, S. ; Kumar, N. and Sharma, P. k. (2014). Extraction and Evaluation of Tvigonella foenum graecum Linn \& Linum Usitatissimum seed mucilage. Global Journal of Pharmacology, 8(4):510-514.

Yusuf, A. K. (2011). Studies on some physicochemical properties of the plant gum exudates of Acacia senegal (Dakwara), Acacia sieberiana (Farar kaya) and Acacia nilotica (Bagaruwa). Journal of Research in National Development, 9, 1596 - 8308. 